NBER WORKING PAPER SERIES

\title{
THE NEW SOCIAL SECURITY COMMISSION PERSONAL ACCOUNTS: WHERE IS THE INVESTMENT PRINCIPAL?
}

\author{
Alan L. Gustman \\ Thomas L. Steinmeier \\ Working Paper 9045 \\ http://www.nber.org/papers/w9045 \\ NATIONAL BUREAU OF ECONOMIC RESEARCH \\ 1050 Massachusetts Avenue \\ Cambridge, MA 02138 \\ July 2002
}

This paper is part of an ongoing project to examine the effects of offering voluntary or mandatory individual accounts under Social Security. Our work was supported by a grant from the U.S. Social Security Administration (SSA) to the Michigan Retirement Research Center, with a subcontract to the National Bureau of Economic Research. The opinions and conclusions are solely those of the authors and should not be construed as representing the opinions or Policy of SSA, the Michigan Retirement Research Center, or the National Bureau of Economic Research. Without implicating them for any errors that remain or for our conclusions, we thank Jeff Brown for helping us to understand the details of the Commission's proposals and for commenting extensively on earlier drafts of this paper, and John Phillips and his colleagues at SSA for their many useful suggestions. The views expressed herein are those of the authors and not necessarily those of the National Bureau of Economic Research.

(C) 2002 by Alan L. Gustman and Thomas L. Steinmeier. All rights reserved. Short sections of text, not to exceed two paragraphs, may be quoted without explicit permission provided that full credit, including (C) notice, is given to the source. 
The New Social Security Commission Personal Accounts:

Where Is the Investment Principal?

Alan L. Gustman and Thomas L. Steinmeier

NBER Working Paper No. 9045

July 2002

JEL No. H55, J26, J14, D31, I3

\begin{abstract}
The President's Commission to Strengthen Social Security suggests three plans for reforming Social Security. These plans divert various amounts of the payroll tax to a personal account if the worker chooses to participate in the account. In return, Social Security benefits are offset using accounts with real returns ranging from $2 \%$ to $3.5 \%$. In addition, the second and third plans proposed by the Commission include features that are designed to balance the finances of the system by reducing the rate of growth of benefits relative to the levels prescribed under current law, to make the system more redistributive, and to make other changes. The measures to increase redistribution and resolve the solvency of the system are relatively separate from the personal accounts.

When "personal accounts" are mentioned, most people think of accounts that are in some sense separate and shielded from the uncertainties of the Social Security system. That is not the case for the personal accounts proposed by the Commission. Because the participating individual is not entitled to the principal in the account, participating in the account does not shield the individual from the political risks of being in the Social Security system. The offset to the plan essentially taxes away the principal in the account, but leaves intact the full Social Security benefit, so that any change in retirement income due to the account reflects the difference in interest earned on the portfolio beyond a stated real rate of interest offset. Thus our analysis describes the account as a financial instrument equivalent to a bet that the real return will exceed the level of offset specified in the plan, ranging from 2 percent to 3.5 percent real. As a result, the reduction in political risk fostered by the Commission's proposals comes mainly from the improvement in the financial status of the system fostered by other provisions of the recommended plans.

Measures to improve the benefits of low income individuals, widows and widowers and to enhance the rewards to retirement all create incentive effects that are also discussed in the paper.
\end{abstract}

\author{
Alan L. Gustman \\ Department of Economics \\ Dartmouth College \\ Hanover, NH 03755 \\ and NBER \\ alan.l.gustman@dartmouth.edu
}

Thomas L. Steinmeier

Department of Economics

Texas Tech University

Lubbock, TX 79409

thomas.steinmeier@ttu.edu 


\section{Introduction}

The report of the President's Commission to Strengthen Social Security (2001) proposes three different plans to establish personal retirement accounts under Social Security and invites comment for a period of a year to foster better understanding of the plans. In this spirit we undertake a series of partial analyses of the individual components of the three plans to better understand their unique economic features. These plans divert various amounts of the payroll tax to a personal account if the worker chooses to participate in the account. In return, Social Security benefits are offset using accounts with real returns ranging from $2 \%$ to $3.5 \%$. In two of the plans, the contribution is fully carved out of payroll taxes, but in the third there is also a matching feature. As we will explain below, a specially structured offset makes the personal accounts fundamentally different from those proposed in some earlier plans. ${ }^{1}$

In addition, the second and third plans proposed by the Commission (CSSS) include features that are designed to make the system more redistributive. Because continuing to pay benefits indefinitely using the present formula is not an option without a major tax increase, these two plans also contain a number of other changes designed to balance the finances of the system. Most importantly, changes in the benefit computation formula would constrain the overall level of real benefits to grow less rapidly than would be true under current law.

The three plans proposed by the CSSS, and especially Plans 2 and 3, were conceived as

${ }^{1}$ There are a number of excellent efforts to project the effects of mandatory accounts under Social Security. Many useful contributions are contained in four recent volumes edited in various combinations by Martin Feldstein, John Campbell, Jeff Liebman and John Shoven, published by the National Bureau of Economic Research. Among the descriptive studies of voluntary privatized systems adopted in other countries, Disney, Palachios and Whitehouse (1999) is the most sophisticated. Gustman and Steinmeier (1998) and Kotlikoff, Smetters and Walliser (1998) analyze participation in and labor supply consequences of a voluntary system of personal Social Security retirement accounts applied to the U.S. economy. 
coherent wholes, consisting of various components that complement each other in an effort to meet the Commission's overall objectives. Nevertheless, it also is useful to understand the economic effects of the individual components of the plans - the particular design for the personal accounts, the approach taken to raise relative benefits for low income individuals and surviving spouses. In this paper we undertake a series of partial analyses of the individual components of the plans. An important caveat is that although most of the components are readily examined individually, because they are part of a plan, it is sometimes appropriate to note the effects of complementary provisions of the plan.

We will discuss these proposals in two parts. The first part will focus on the proposals for personal accounts. There are two reasons that people want private accounts. One is to earn a higher return than has been available on social security. The second is to reduce political risk by diversifying retirement assets out of social security, which has become vulnerable due to the financial status of the system. Without meaning to be pejorative, but to highlight its unique characteristics, we describe the account as a financial instrument equivalent to a bet that the real return will exceed the level of offset specified in the plan, ranging from 2 percent to 3.5 percent. Because the offset taxes away the principal in the account, the account itself does not contribute much to the reduction of political risk. The second part of the discussion will focus on those aspects of the Plans 2 and 3 having to do with redistribution and funding of the traditional program. The provisions relating to redistribution and funding can be implemented whether or not personal accounts are made part of the system, and indeed some combination of them would probably be essential unless taxes were raised under the current system sufficiently to absorb the entire shortfall, which would be contrary to one of the major constraints placed on the CSSS by the President. 
The major changes in the system that we will discuss are summarized in Table 1, which reorders and rewords a table from the Commission report. It will be apparent from this discussion that overall financial balance and redistribution could also be attained by combining these features in other ways from those specified under Plans 2 and 3.

\section{Personal Accounts}

Personal accounts under all three plans work in much the same way. Some percentage of the taxes is diverted to the personal accounts. Upon retirement, the accounts are converted to annuities, and benefits payable under the traditional system are reduced. The amount of reduction is calculated by assuming that the diverted contributions grow at some fixed real rate, and then annuitizing the resulting amount. The main difference between the plans is in the amounts. Plan 1 allows 2 percent of OASDI taxable income to be so diverted. Plan 2 allows 4 percent up to $\$ 1,000$, and Plan 3 allows 2.5 percent up to $\$ 1,000$ if the worker contributes an additional 1 percent of wages.

A critical factor in understanding these plans is understanding the nature of the offset. For convenience we will look at Plan 1, where the offset is accrued at a real rate of 3.5 percent. Suppose that the funds in the personal account grew at 3.5 percent, and that at the time of retirement, these funds amounted to $\$ 20,000$. The account would be annuitized at a real rate that would be appropriate for the individual, or for the individual and the spouse, if married. Suppose that the annuity is $\$ 1,000 .^{2}$ However, the same $\$ 1,000$ would be subtracted from the benefits that the individual would otherwise be paid from the traditional system. That is to say, if the actual performance of the fund is equal to the specified real growth rate of the offset amount, the individual will be in exactly the same position as in the traditional system. The taxes paid will

\footnotetext{
${ }^{2}$ In certain cases there may be a partial lump sum settlement permitted.
} 
be the same, and the benefits will be the same.

Suppose instead that the funds in the personal account grew at 5 percent, so that at the time of retirement the funds amounted to $\$ 23,000$. After annuitization, the annual amount would be $\$ 1,150$. The offset from the traditional benefits would still be $\$ 1,000$, so the individual would have annual benefits that were higher by $\$ 150$. In this case, the only difference between what the individual would collect in the personal account system and the traditional system would be the difference between the realized interest rate and 3.5 percent. If the realized rate is equal to the rate used in the offset calculations, the individual is no better and no worse off than he or she would be in the traditional system. In simplest terms, the net benefit from the account is given by:

Net benefit $=($ account principal + earned interest $)+$ social security benefit $-($ account principal + offset interest). ${ }^{3}$

Plans 2 and 3 are essentially the same, except that the real rate used in calculating the offset is 2 percent and 2.5 percent, respectively, making it more likely that the return on the investment will exceed the offset rate. For Plan 3, the redirected payroll taxes, but not the

${ }^{3}$ If there are " $\mathrm{t}$ " years to retirement and if the private account under Plan 1 will earn a real return at rate " $\mathrm{r}$ ", a person who chooses to direct $2 \%$ of payroll to the account at retirement age will receive a real annuity equal in present value to $(1+\mathrm{r})^{t}$ times the $2 \%$ contribution. In addition, the person receives the basic Social Security benefit. The offset is an annuity equal in present value to the balance of an account worth $(1+.035)^{t}$ times the $2 \%$ contribution. Thus under the program, the net benefit is the basic Social Security benefit plus $\left[(1+\mathrm{r})^{t}-(1.035)^{t}\right]$ times the $2 \%$ contribution. The last term says that what they receive is the difference in the interest rate applied to the basic contribution, but it does not include the base of their contribution, equal to the $2 \%$ payroll tax contribution deposited in the account. An exception that is theoretically possible, but has very low probability should be noted. The value of the social security benefit account offset has a lower limit of zero. In the very unlikely circumstance that social security benefits were abolished entirely, an account holder would be entitled to the principal in the account plus earned interest. But in the range of likely outcomes, the effective account balance is zero. 
voluntary contributions, are used in the offset computations.

\section{Political Risk}

There is another factor in these calculations, however. The current system is unsustainable, and through some means or other, either the future benefits payable under the current benefit formula will have to be reduced from the levels that the formula indicates, or taxes raised. The risk that benefits will have to be reduced may be termed the "political risk," as opposed to the investment risk by which investments may perform better or worse than expected.

Now let us consider how participation in the personal pensions will affect the benefits payable in the presence of political risk. We continue to look at the same individual as before, except that now we specify that his traditional benefits are $\$ 10,000$ per year. With the personal accounts, the traditional benefits would be $\$ 9,000$ and the benefits from the account, at a realized real rate of 5 percent, would be $\$ 1,150$. Suppose that in order to resolve the funding imbalance, traditional benefits must be reduced to $\$ 8,500$. If the individual stays in the traditional system, that is the amount he or she will get. With the personal account, the offset will still be calculated at a 3.5 percent real rate, which would yield an annual offset of $\$ 1,000$. The individual would receive a benefit of $\$ 7,500$ from the traditional system and $\$ 1,150$ from the personal account, resulting in benefits of only $\$ 8,650$.

The bottom line of this example is that participation in the personal account has not shielded the individual from the political risk at all. If the funding status dictates that the full traditional benefit must be reduced by $\$ 1,500$, the individual's combined benefit will be reduced by $\$ 1,500$ whether he or she is in the personal plan or not. The advantage, and the only advantage, to being in the personal plan is the possibility of receiving a real interest rate of greater than 3.5 percent in the personal account. If the realized rate is equal to 3.5 percent, the 
individual will receive exactly the same combined amount whether or not he or she is in the personal plan. The hope, of course, is that the personal plans will earn more than 3.5 percent, which would take some of the sting out if benefits must be reduced relative to the current formula. But that is not a certainty.

The same point applies to the individual account in CSSS Plans 2 and 3, which will be discussed in the next section. However, Plans 2 and 3 contain other elements that try to make the trust fund more solvent. In this respect the other elements of the plan may reduce political risk. But because of the particular way the offset provisions to the personal account plans work, other things the same, the benefits in Plans 2 and 3 will differ only by the interest differential, and in the face of benefit changes, will provide roughly the same ultimate benefit whether or not the individual opts for the personal plans. Again, the only advantage of the personal plans is that the individual has the potential to earn more than the 3.5 percent (or the applicable rate for the plan in question) in the personal plan. This is the source of the statement we made in the introduction that the accounts are essentially a financial instrument equivalent to a bet that the real return will exceed the offset level specified in the plan, ranging from 2 percent to 3.5 percent real.

\section{Alternative Conceptions of Personal Accounts}

When you mention "personal accounts," most people think of accounts that are in some sense separate and shielded from the uncertainties of the Social Security system. That is most certainly not the case for the personal accounts proposed by the Commission. Being in these accounts does not in any way shield the individual from the political risks of being in the Social Security system. Any reduction in political risk must come from other provisions of the plan.

It is not difficult to conceive of accounts that match individuals' perceptions of what personal accounts should be. Perhaps the simplest is along the following lines: you put 10 
percent of your combined employer and employee payroll taxes into personal accounts, and you will receive 90 percent of the traditional benefits which otherwise would be payable to you. You will receive in addition the annuity from the personal account. If the birth rate falls through the floor and traditional benefits must be cut by 75 percent, at least the principal and interest in the personal account is safe. On the other hand, if babies become popular again and it is possible to raise traditional benefits, you will only get 90 percent of the amount of the bounty, but again you will have the personal account.

Why did the Commission adopt the real interest offset approach rather than a proportional benefit approach? The Commission listed three reasons. 1. Because the benefit formula is progressive, a flat offset formulation would mean larger relative reductions in traditional benefits for low-income workers. 2. Because a contribution at a younger age has a longer period in which to compound, a contribution at age 50 should not produce the same percentage offset as an equal contribution at age 25 , which a flat percentage offset would do. 3 . Workers will have a readily understood standard by which to choose whether to opt for a personal account. (Report, page 100) "Under this formulation, the individual need not master the complexities of Social Security's benefit calculation. He knows that he is getting more benefits than he is giving up if his personal account return exceeds the offset interest rate." (Report, p. 99) Nevertheless, the Commission also notes "... that these concerns do not mean that flat percentage offsets should be ruled out as a policy option. We note, however, that such a design would likely require additional policy changes in order to reach distributional goals." (Report, p. 100)

The Commission did not discuss the implications of the proposed personal account offsets for political risk. Personal accounts certainly do not reduce the political risk in the aggregate, and they would seem to increase it in the short and intermediate term because taxes 
are diverted away from the trust fund long before they lower demand to pay traditional benefits. A proportional benefit approach would have shielded the personal accounts from this increased political risk and hence could have been an important factor in encouraging individuals to choose the accounts. And yet the Commission went the other way, relying on other provisions of Plans 2 and 3, but not the account structure to reduce political risk.

Nor does the argument that a universal move to personal accounts is regressive get very far. Several studies have shown that in the present system, the progressive nature of the benefit formula is approximately offset by the higher mortality rates of low income workers coupled with the higher percent of spouse and survivor benefits going to high income single earner families. ${ }^{4}$ The net result is that the current system is not very progressive over most of the household income distribution. The proportional benefit approach would reduce taxes and expected benefits proportionally, and would not change the distribution very much. The main impact would come from a forced annuitization of the personal accounts, which would be less attractive to lower income, higher mortality workers.

A perhaps more fruitful approach to understanding the Commission's choice would also look at who would choose personal accounts under a proportional benefit system. If returns under Social Security are lowest for high income singles and high income dual worker families, they will be the ones most likely to opt out and the personal accounts. The nature of much of the debate, in terms of possible means tested benefits, special deals for low income groups, and the other proposals which have been circulated, probably makes it appear that higher income groups face a greater share of the political risk, which would make them doubly anxious to move to

${ }^{4}$ See Steurle and Bakija (1994), Liebman, (2000), and Coronado, Fullerton and Glass (2000) in addition to Gustman and Steinmneier (2001). 
personal accounts which shielded them from that risk. As the higher income groups disproportionately accept personal accounts, the political risk would be disproportionately concentrated among the lower income groups, which goes against the Commission's general tendency to favor redistribution towards these groups.

The offset approach suggested by the Commission makes it essentially impossible to escape the political risk by choosing the personal accounts. The cost is that the personal accounts lose some of their appeal, and that they essentially become bets that the return on the personal accounts will exceed the interest rate specified in the offset provision of the particular plan.

One final reason for the Commission's choice of offset for the private account may be that it has faith that the provisions of Plans 2 and 3 meant to bolster solvency of the system will do the job. Although the personal accounts are not in and of themselves a safe haven from the winds of uncertainty swirling around the Social Security system, the other changes introduced in Plans 2 and 3 that enhance the financial stability of the system substantially reduce the underlying political risk facing holders of private accounts, reducing the importance of adopting a more traditionally structured offset plan.

\section{Funding and Distributional Changes}

We now turn to the changes in Plans 2 and 3 designed to move the system closer to longterm solvency and to create redistributions toward disadvantaged groups. It should be recognized early that these features, listed in Table 1, are more or less independent of the personal accounts. Under the two plans including these changes, they will have exactly the same effect on an individual whether or not they choose to participate in the personal plan. Indeed, they could equally well be implemented with the current system, with roughly similar results. 
There is something of a mix and match quality to these changes in that various combinations of them could be adopted to achieve the funding objectives while generating various amounts of redistribution.

With the proposed benefit changes, Plan 2 roughly achieves solvency, although it requires some temporary transfers from the Treasury during the intermediate years. Plan 3 also achieves solvency, although it calls for some permanent transfers from the general budget. These changes are an alternative to the outcome in the absence of specific policy, achieving balance under Plan1 (and current law) by waiting until the trust funds run out and then paying only a fraction of the calculated benefits.

\section{Limit the Growth of Benefits (Plans 2 and 3)}

Both Plans 2 and 3 would gradually and proportionally reduce the multiplicative factors in the PIA formula. In Plan 2, these adjustments would be sufficient for the average benefits of successive cohorts to grow proportionally to the CPI, instead of proportionally to average wages as is now the case. Another way of saying this is that average benefits would be frozen in real terms, instead of rising with real wages as they currently do. Successive generations would continue to receive the same real benefits; only these real benefits would be an ever declining proportion of their real wages, and by implication of their real taxes. Plan 3 is similar except that the reductions in the multiplicative factors in the PIA formula are set to roughly offset the effects of increasing longevity. The growth rate of benefits under Plan 3 would be roughly midway between the zero real growth rate of Plan 2 and the (unsustainable) growth rate under current law.

The primary effect of this provision is to bring the system back toward solvency, and the amounts saved here are huge, the equivalent of over 2 percent of the total payroll over the 75 
year period for Plan 2 and over 1 percent for Plan 3. The larger impact of Plan 2 is largely what allows it to achieve solvency without any permanent transfers from the general budget. Because the reductions in the benefit formula are proportional, the provision has minimal effects on the distribution of income with a particular cohort. While the reductions in the PIA formula are cumulative and relatively larger further down the road, it is not clear that this provision works against later generations any more than other measures to resolve the funding shortfall. Recall that if no action is taken, benefits will eventually fall by a quarter to a third, and this might have an even larger negative impact on later generations.

\section{Modify the Actuarial Reduction and Increment Factors (Plan 3)}

Current law calls for benefits to be reduced by 20 percent for someone retiring three years before the normal retirement age and 30 percent for someone retiring five years before that age. Benefits would increase by 8 percent for each year the individual retires after the normal retirement age. Plan 3 calls for these percentages to increase to 25 percent, 37 percent, and 10 percent. The stated intent of this provision is to provide greater incentives to continue working. ${ }^{5}$ However, for individuals retiring after the normal retirement age, the recent repeal of the earnings test already makes it possible to collect benefits whether or not the individual is working. Hence the increase in incentives after the normal retirement age is largely a change in the incentives to start collecting benefits, not to delay retirement. The net effect of the proposal to increase the rewards to delay collecting benefits is likely to be to increase costs to the system, since 10 percent is a more than actuarially fair rate, without providing many with an incentive to

\footnotetext{
5 "Work would be rewarded and early retirement penalized by changing the actuarial adjustments for early and late retirement to reflect additional payroll taxes contributed. This change is designed to encourage labor force participation among workers age 62-70." Report, $\mathrm{p}$. 132.
} 
continue working past the normal retirement age.

For individuals retiring before the normal retirement age, the increase in the penalties to retire early is probably the most important provision proposed by the commission to affect the retirement age. The provision clearly alters the rewards to retiring at different ages, rather than simply moving the whole profile up or down. Measures that alter the incentives to retire at different ages generally have more impact than measures that move the compensation profile up or down but do not significantly alter the rewards of retiring in a particular year relative to retiring in nearby years.

The provision has significant budgetary and distributional implications too, however. Because the median retirement age is 62 , and because the overwhelming percentage of individuals collect benefits within a few months of retirement, more individuals will be facing steeper increases in their reduction factors than will benefit from the increases in the credit for retiring after the normal retirement age. This effect is substantial, with the budget savings being more than half of the budget savings from limiting the growth of benefits previously discussed.

The provision may also have some distributional effects. Many workers collect benefits at 62 because they want to enjoy retirement, and have a pension that encouraged them to leave their jobs; but there is also a substantial number of generally low income workers who may have health problems and who retire at age 62. To the extent that low income workers are disproportionately likely to begin collecting benefits at age 62 , this provision will be regressive, in contrast with the other redistributive measures which are generally on the progressive side. Additional Benefits for Low Wage Workers (Plans 2 and 3)

Plan 2 would raise the PIA for minimum wage workers with 30 years or more of coverage by 40 percent. This increase would be gradually phased out for workers earning twice 
the minimum wage or workers with 20 years or less of coverage. This provision would be phased in over the period 2009 to 2018 . Plan 3 has a similar feature, but with different numbers. The increase for a minimum wage worker with 30 years of coverage would be 12 percent. It would be phased out for workers earning the average wage and for workers with 20 years or less of coverage. In Plan 2, for low wage workers with more than 30 years of coverage, the increase would be scaled up for years of coverage up to 40 .

In addition to increasing progressivity, these provisions also create some interesting incentive effects. An obvious effect is that they increase the reward to many minimum wage and near-minimum wage workers for additional work. A less obvious effect is that since it takes only minimal earnings to qualify for a year of coverage under Social Security, low wage workers will have incentives to spread their work over as many years as possible. A worker who earns $\$ 2,000$ a month for six months for 40 years will be in a much better position, as far as Social Security benefits are concerned, than someone else who earns $\$ 2,000$ a month for twelve months for 20 years. Early periods of occasional work, even summer jobs, could conceivably have a noticeable impact on benefits under these proposals.

These provisions also create some interesting contrasts between workers with different incomes. As an illustration, consider two 35 year workers in Plan 2, one at the minimum wage (\$11,318 in 2009) and the other at twice the minimum wage $(\$ 22,635) .{ }^{6}$ Under the current law and using the 2001 bend points, the PIA of the minimum wage worker would be $\$ 7,526$ and the PIA of the twice-minimum wage worker would be $\$ 11,148$. Under Plan 2, the PIA of the minimum wage worker would rise to $\$ 10,156$, while the PIA of the twice-minimum wage worker

${ }^{6}$ See page 5 of the Actuaries Memo attached to the Report (2001) for the minimum wage measures and percentage increases in the PIA for this provision, which is phased in from 2009 to 2018. 
would stay at $\$ 11,148$. This illustration shows that under the Plan 2 proposal, the PIA is approximately constant over a wide interval.

Reduce Benefits for High Wage Workers (Plan 3)

Plan 3 would gradually reduce the top bracket in the PIA formula from 15 percent to 10 percent. This change serves two purposes. It increases the progressivity of the system, but it also provides a modest contribution to the solvency of the system. Increase Benefits for Low Wage Widows and Widowers (Plans 2 and 3)

Both Plans 2 and 3 would increase the benefits of widows and widowers who would otherwise receive benefits less than the average PIA to $75 \%$ of the benefits that the couple could collect if both had lived. Widows and widowers with benefits above the average PIA would not be affected and would receive benefits according to current laws.

This element of the plan would actually worsen the solvency of the system (but not by much), but it would address what some view as a shortcoming of the current system, namely, that the system does a much better job of keeping couples out of poverty than it does of keeping one spouse out of poverty if the other spouse dies.

\section{Implications}

The President's Commission to Strengthen Social Security (2001) invited comments for a period of a year to foster better understanding of the three plans they were proposing. There are a number of features of the Commission's plans that have unusual implications and are deserving of further study.

The personal accounts are somewhat different from those that most people would visualize when you mention "personal accounts." These accounts provide the participants with the possibility of a higher return, but because under most circumstances the participants are not 
entitled to the principal in the accounts, by themselves the accounts do not protect participants from the political risks in the Social Security system. Other features of Plans 2 and 3 do, however, reduce the amount of remaining political risk facing account holders. The accounts turn out effectively to be financial instruments which yield the returns of the account less a return specified by the plan -- bets that the return on one's own investment will exceed the specified return under the plan, from 2 percent to 3.5 percent real. Changes to the traditional system, whether those specified in Plans 2 and 3 or the unspecified changes which are probable under Plan 1, will have the same effect on individuals whether or not they have enrolled in a personal plan.

If policy makers were willing to make the account mandatory instead of voluntary, there would be no concern with certain groups having a greater incentive to opt out of the conventional program into private accounts. That would eliminate some of the disadvantages of structuring the offset as proportional to the share of taxes deposited in the account. A proportional offset would have the advantage of allowing participants to own the principal in the account as well as the interest earned in the market, and thereby mitigate political risk to their future Social Security benefits.

The measures to increase redistribution and resolve the solvency of the system are relatively separate from the personal accounts. To be sure, the greater the reduction in benefits from the (unsustainable) levels projected under current formulas, the lower the offset to the private account that can be afforded. Nevertheless, the effects of the measures to increase redistribution and resolve the solvency of the system on individuals do not depend on whether an individual has a personal account, and by and large these measures could be applied to the current system without personal accounts with similar effect. These proposals do contain many 
new incentive effects which could affect when individuals retire, although as we have noted, the incentive to delay retirement from the proposed increase in the delayed retirement credit is largely offset by the fact that the earnings test has been abolished for those over 65 . We know from previous work that many of these incentive effects will be small, but the complexity of the changes in the benefit structure mean that some of the effects could be substantial. Once isolated, these incentive effects should be compared with those that will arise from alternative efforts to balance the current system, particularly if these involve the introduction of new taxes. 


\section{References}

Campell, John Y. and Martin Feldstein, editors. 2001. Risk Aspects of Investment-Based Social Security Reform. Chicago: University of Chicago Press.

Coronado, Julia Lynn, Don Fullerton and Thomas Glass. 2000. “Long Run Effects of Social Security Reform Proposals on Lifetime Progressivity”. Paper presented at NBER conference on Distributional Aspects of Social Security and Social Security Reform. October.

Disney, Richard, Robert Palacios and Edward Whitehouse. 1999. "Individual Choice of Pension Arrangement as a Pension Reform Strategy". Xerox, July.

Feldstein, Martin, editor. 1998. Privatizing Social Security. Chicago: University of Chicago Press.

Feldstein, Martin and Jeff Liebman, editors. 2002. The Distributional Aspects of Social Security and Social Security Reform. Chicago: University of Chicago Press.

Feldstein, Martin and Andrew A. Samwick. 1998. "The Transition Path in Privatizing Social Security". In Martin Feldstein, editor. Privatizing Social Security. Chicago: University of Chicago Press for NBER. Pp. 215-260. . 2000. "Allocating Payroll Tax Revenue to Personal Retirement Accounts". Tax Notes, pp. 1645-1652.

Gustman, Alan L. and Thomas L. Steinmeier. 1998. "Privatizing Social Security: FirstRound Effects of a Generic, Voluntary, Privatized U.S. Social Security System”. In Martin Feldstein, editor. Privatizing Social Security. Chicago: University of Chicago Press for NBER. Pp. 313-357.

. 2001a. "How Effective Is Redistribution Under the Social Security Benefit Formula". Journal of Public Economics, forthcoming. Paper presented at MRRC 
Conference, May 2000.

Kotlikoff, Laurence J., Kent Smetters and Jan Walliser. 1998. “Opting Out of Social Security and Adverse Selection". Washington, D.C.: Congressional Budget Office, Technical Paper Series, Macroeconomic Analysis and Tax Analysis Divisions.

Liebman, Jeffrey B. 1999. "Redistribution in the Current U.S. Social Security System". Paper presented at NBER conference on Distributional Aspects of Social Security and Social Security Reform. October.

President's Commission to Strengthen Social Security. 2001. "Strengthening Social Security and Creating Personal Wealth for All Americans". Washington, D.C.: December. http://www.commtostrengthensocsec.gov/reports/Final report.pdf

Shoven, John B, editor. 2000. Administrative Aspects of Investment-Based Social Security Reform. Chicago: University of Chicago Press.

Steuerle, C.E. and J.M. Bakija. 1994. Retooling Social Security for the Twenty First Century: Right and Wrong Approaches to Reform. Washington, D.C.: Urban Institute. 
Table 1: Elements of Commission Reform Models

\begin{tabular}{|c|c|c|c|}
\hline & Plan 1 & Plan 2 & Plan 3 \\
\hline \multicolumn{4}{|c|}{ I. Personal Accounts } \\
\hline Size & $\begin{array}{l}2 \% \text { of earnings } \\
\text { up to maximum }\end{array}$ & $\begin{array}{l}4 \% \text { of earnings to } \$ 1000 / y r \text { (wage } \\
\text { indexed) }\end{array}$ & $\begin{array}{l}1 \% \text { new contribution }+2.5 \% \text { of payroll } \\
\text { tax to } \$ 1000 / y r \text { (wage indexed) }\end{array}$ \\
\hline Offset & $3.5 \%$ real & $2 \%$ real & $2.5 \%$ real \\
\hline \multicolumn{4}{|c|}{ II. Funding and Distributional Changes } \\
\hline $\begin{array}{l}\text { Limit Growth of Traditional } \\
\text { Benefits }\end{array}$ & None & Indexed to inflation instead of wages. & $\begin{array}{l}\text { Reduced to offset the gain in life } \\
\text { expectancy (= inflation }+0.5 \%)\end{array}$ \\
\hline $\begin{array}{l}\text { Modify Actuarial Return } \\
\text { and Increment Factors }\end{array}$ & None & None & $\begin{array}{l}\text { Early retirement benefit reduced, late } \\
\text { benefit increased }\end{array}$ \\
\hline $\begin{array}{l}\text { Additional Benefits for Low } \\
\text { Wage Workers }\end{array}$ & None & $\begin{array}{l}\text { Benefit to } 30 \text { year minimum wage } \\
\text { worker }=120 \% \text { of poverty, inflation } \\
\text { indexed. }\end{array}$ & $\begin{array}{l}\text { Benefit to } 30 \text { year minimum wage } \\
\text { worker }=100 \% \text { of poverty, wage } \\
\text { indexed. }\end{array}$ \\
\hline $\begin{array}{l}\text { Reduce Benefits for High } \\
\text { Wage Workers }\end{array}$ & None & None & $\begin{array}{l}\text { Reduce highest income bend point } \\
\text { from } 15 \% \text { to } 10 \%\end{array}$ \\
\hline $\begin{array}{l}\text { Increase Benefits for Low } \\
\text { Wage Widows and } \\
\text { Widowers }\end{array}$ & None & $\begin{array}{l}\text { For low wage couples, increased to } \\
75 \% \text { of couple benefit. }\end{array}$ & $\begin{array}{l}\text { For low wage couples, increased to } \\
75 \% \text { of couple benefit. }\end{array}$ \\
\hline
\end{tabular}

Other features of the programs are not shown. 